\title{
The Grey-Based Taguchi Method: Optimization of Milling of Mold Steel
}

\author{
G. BASMACI ${ }^{a}, \mathrm{M} \mathrm{AY}^{b, *}$ AND A. ETYEMEZ ${ }^{c}$ \\ ${ }^{a}$ Mehmet Akif Ersoy University, The Faculty of Engineering and Architecture \\ ${ }^{b}$ Marmara University, Faculty of Technology, 34722, Istanbul, Turkey \\ ${ }^{c}$ Nikket Türkiye, Girne Mah. Irmak Sk., Kü̧̈ükyalıİş Merkezi, A Blok, No:5, 34852 Maltepe/İstanbul \\ In this study, surface roughness and cutting forces were experimentally investigated in a PMD 23 cold work \\ tool steel milled with multi-layer $\mathrm{Al}_{2} \mathrm{O}_{3}+\mathrm{TiCN}$ coated cutting tools. The effects of progress rate, cutting speed \\ and cutting depth on surface roughness and cutting forces were investigated. The Taguchi technique was used to \\ optimize the milling process. With this study, optimal machinability of PMD 23 cold work tool steel with multi-layer \\ $\mathrm{Al}_{2} \mathrm{O}_{3}+\mathrm{TiCN}$ coated tools was determined by Taguchi Grey based optimization technique. The optimum value is \\ obtained by Taguchi based Grey relational analysis when the machining parameters are as follows: $500 \mathrm{~mm} / \mathrm{min}$ \\ feed, $3500 \mathrm{rpm}$ spindle speed and $1.0 \mathrm{~mm}$ cutting depth (A1B3C2).
}

DOI: 10.12693/APhysPolA.134.24

PACS/topics: Taguchi method, Grey relational analysis, surface roughness, cutting force, milling

\section{Introduction}

Materials with high strength have been obtained with the developments in the material technology. The choice of the appropriate cutting tool when removing the chip over these materials is important for increasing efficiency [1-13]. The choice of tool material and cutting geometry is also very important. Even if the tool is selected appropriately, the efficiency declines if the processing conditions are out of standard. In order to perform high-efficiency and economical processing, it is necessary to carry out theoretical studies of each kind of material and cutting tool to be processed $[1,2,6-8,10]$.

Among the manufacturing methods, cutting processing methods have an important place. Milling is widely used among cutting processing methods. There are many methods of milling. One of these methods, the surface milling, is the most commonly used type of swarf processing. Surface milling can be done with penknives with various properties, but it is common to process by using insert tips. These tips have the ability to handle materials with different properties. It is important to achieve high dimensional accuracy and geometrical properties. In order to accomplish this, the PMD 23 material was tested using different tips. This material is the cold work steel of the powder metallurgy production. Its abrasion resistance and toughness is several times higher than that of the known $12 \% \mathrm{Cr}$ steels. The features of the material are more evident with punches and molds that are cutting, punching, pressing, and blowing. It also gives very good results in cutting tools such as milling, and reamer. Compared to 1.3343, it has many times higher endurance and can operate at higher speed.

\footnotetext{
*corresponding author; e-mail: muay@marmara.edu.tr
}

Austenitic stainless steels similar to this material are made of chrome-nickel steels and provide very high corrosion resistance. It is not recommended to use other alloys for a wide range of excellent mechanical properties. The austenite group of stainless steels is a group of non-magnetic materials and even though they are cold strengthened for cold work, they cannot be hardened by conventional heat management process [14]. AISI 304 Austenitic stainless steel is categorized under the group of materials that are difficult to process. In the machining operations of Austenitic stainless steels, side abrasions, crater surfaces and irregular abrasions usually occur in the tool [15].

Such reasons as poor workability of this material, work hardening rates, high unbreakable endurance, high tendency power, high ductility and very low thermal conductivity explain the situation $[15,16]$. Work hardening of this steel will cause an increase in tool abrasion and tool damage. Reducing the effect of work hardening in tool life can be achieved with a hard tool and a high progression rate [17].

Milling of high-hardness steels causes the tool life to decrease. In addition, there is occasional cooling repetition throughout the shear, and periodic temperature variation causes micro-cracks in the inserts. Therefore, the thermal properties of tool materials, such as thermal conductivity, are very important characteristics in milling of hard materials. The measurement of the tool temperature is necessary to evaluate the feasibility of the tool for milling. However, it is difficult to accurately measure the temperature of the tool because the cutting tool rotates at high speed and the measurement area is small.

In most of the literature, hardened steels are processed at high speed. A large part of the literature related to hardened steels refers to the AISI H13 hot working tool steel, and this steel is used in the production of a wide range of molds and in hot matrix forms [18-24]. 
In this study, the machinability of PMD 23 material was investigated using multi-layer $\mathrm{Al}_{2} \mathrm{O}_{3}+\mathrm{TiCN}$ coated inserts with different progress and cutting depths. Taking into account the industrial conditions, the Taguchi experimental design method was used to be able to carry out these experiments in the most efficient way, considering the economic conditions and time constraints, as well as to interpret the results correctly and to obtain the best results with optimum experimentation. Through this study, the optimal machinability of PMD 23 cold work tool steel with multi-layer $\mathrm{Al}_{2} \mathrm{O}_{3}+\mathrm{TiCN}$ coating was determined by Taguchi Grey based optimization technique. The optimum value is obtained by Taguchi based Grey relational analysis for the following machining parameters: $500 \mathrm{~mm} / \mathrm{min}$ feed, $3500 \mathrm{rpm}$ spindle speed and $1.0 \mathrm{~mm}$ cutting depth (A1B3C2).

\section{Materials and methods}

\subsection{Materials}

MD 23 cold-work tool steels are used in the mold industry. PMD 23 cold-work tool steel has high temperature stability, thermal conductivity, toughness and wear resistance. Specimens used in the experimental study were made of PMD 23 cold work-tool steel material, chemical composition and mechanical characteristics of which are given in Table I and Table II, respectively. JOHNFORD VMC-850/550+APC CNC Fanuc 0T x-y-z axis CNC Milling Machine with a motor power of $30 \mathrm{HP}$ was used in experiments.

TABLE I

Chemical composition of PMD 23 cold work-tool steel.

\begin{tabular}{c|c|c|c|c}
\hline \hline PMD 23 & C & W & Cr & V \\
\hline Fe based & 1.30 & 6.40 & 4.2 & 3.10
\end{tabular}

TABLE II

Mechanical characteristics of PMD 23 cold work-tool steel.

\begin{tabular}{c|c|c|c|c}
\hline $\begin{array}{c}\text { Tensile } \\
\text { strength } \\
{[\mathrm{Mpa}]}\end{array}$ & $\begin{array}{c}\text { Yield } \\
\text { strength } \\
{[\mathrm{Mpa}]}\end{array}$ & $\begin{array}{c}\text { Elongation } \\
{[\%]}\end{array}$ & $\begin{array}{c}\text { Density } \\
{\left[\mathrm{kg} / \mathrm{m}^{3}\right]}\end{array}$ & $\begin{array}{c}\text { Hardness } \\
{[\mathrm{HB}]}\end{array}$ \\
\hline 460 & $530-650$ & 24 & $25-36$ & 460
\end{tabular}

The following equipment was used in experiments; JOHNFORD VMC-850/550+APC CNC Fanuc 0T x-y$\mathrm{z}$ axis CNC Milling Machine, multi-layer $\mathrm{Al}_{2} \mathrm{O}_{3}+\mathrm{TiCN}$ coated inserts, MAHR-Perthometer surface roughness tool for surface roughness measurement, KISTLER 9265B dynamometer for cutting force measurement and KISTLER 5019b type charge amplifier. DynoWare software was used for the analysis.

\subsection{Method}

Experiment was designed by using Taguchi technique. This way it was possible to achieve more comprehensive results with lesser number of experiments. In this case, time and cost have been saved. As surface roughness of the surface to be measured and cutting force rates are required to be minimum in determination of the quality characteristics, the principle of "the smallest is the best" was used for the quality values expected to be found as a result of the experiments. In this experimental study, tool path, feed and cutting depths were chosen as parameters. Multiple-layer $\mathrm{Al}_{2} \mathrm{O}_{3}+\mathrm{TiCN}$ coated inserts were used in all experiments. The parameters and their levels are presented in Table III. L9 experimental design together with surface roughness and cutting forces obtained from the experiments are given in Table IV.

Experimental variables.

TABLE III

\begin{tabular}{l|c|c|c}
\hline \hline Parameters & $\begin{array}{c}(\mathrm{A}) \\
\text { Feed } \\
{[\mathrm{mm} / \mathrm{min}]}\end{array}$ & $\begin{array}{c}(\mathrm{B}) \\
\text { Spindle speed } \\
{[\mathrm{rpm}]}\end{array}$ & $\begin{array}{c}(\mathrm{C}) \\
\text { Cutting depth } \\
{[\mathrm{mm}]}\end{array}$ \\
\hline Level I & 500 & 2800 & 0.5 \\
Level II & 850 & 3000 & 1.0 \\
Level III & 1200 & 3500 & 1.5
\end{tabular}

TABLE IV

L9 experimental setup, surface roughness and cutting force values.

\begin{tabular}{c|c|c|c|c|c|c}
\hline \hline $\begin{array}{c}\text { Exp. } \\
\text { no. }\end{array}$ & Variables & $(\mathrm{A})$ & $(\mathrm{B})$ & $(\mathrm{C})$ & $\begin{array}{c}\mathrm{Ra} \\
{[\mu \mathrm{m}]}\end{array}$ & $\begin{array}{c}\text { Cutting } \\
\text { force } \\
{[\mathrm{N}]}\end{array}$ \\
\hline 1 & $\mathrm{~A}_{1} \mathrm{~B}_{1} \mathrm{C}_{1}$ & 1 & 1 & 1 & 0.541 & 311 \\
2 & $\mathrm{~A}_{1} \mathrm{~B}_{2} \mathrm{C}_{2}$ & 1 & 2 & 2 & 0.335 & 353 \\
3 & $\mathrm{~A}_{1} \mathrm{~B}_{3} \mathrm{C}_{3}$ & 1 & 3 & 3 & 0.287 & 372 \\
4 & $\mathrm{~A}_{2} \mathrm{~B}_{1} \mathrm{C}_{2}$ & 2 & 1 & 2 & 0.703 & 469 \\
5 & $\mathrm{~A}_{2} \mathrm{~B}_{2} \mathrm{C}_{3}$ & 2 & 2 & 3 & 0.652 & 584 \\
6 & $\mathrm{~A}_{2} \mathrm{~B}_{3} \mathrm{C}_{1}$ & 2 & 3 & 1 & 0.675 & 417 \\
7 & $\mathrm{~A}_{3} \mathrm{~B}_{1} \mathrm{C}_{3}$ & 3 & 1 & 3 & 0.984 & 715 \\
8 & $\mathrm{~A}_{3} \mathrm{~B}_{2} \mathrm{C}_{1}$ & 3 & 2 & 1 & 0.896 & 598 \\
9 & $\mathrm{~A}_{3} \mathrm{~B}_{3} \mathrm{C}_{2}$ & 3 & 3 & 2 & 0.809 & 646
\end{tabular}

\subsection{Taguchi based Grey relational analysis}

The obtained experimental results and the determined parameters were optimized with Grey based Taguchi method. Using regression model, research was carried out by calculating an equation between the dependent and independent parameters. The Taguchi method uses a special design of orthogonal arrays to study the entire parameter space with a small number of experiments only.

Experimental design was done using Taguchi method. Hence, it was possible to reach more comprehensive results while doing less experiment. In this sense, time and money have been used more efficiently [25-28]. While the only outcome is optimized in the Taguchi method, multiple outcomes can be optimized in a Grey relational analysis [28]. In this study, Taguchi method was used in the experimental design step. Grey relational analysis method was used in the optimization step.

Optimization process of Grey relational analysis was carried out in the following steps [28]; 
1. Normalization of experimental results (the lowest the best)

2. Calculation the Grey relational coefficient

3. Calculation of the Grey relational degree

4. Determination of optimal experiment parameters

In the normalization step, the experimental results were normalized using the below equation, according to "the lowest - the best" principle

$$
x_{i}(k)=\frac{\max y_{i}(k)-y_{i}(k)}{\max y_{i}(k)-\min y_{i}(k)},
$$

where, $\mathrm{x}_{i}(k)$ refers to the value of the $i$ series and $k$ row after normalization process, $\min y_{i}(k)$ refers to the minimum value of the $i$ series, $\max y_{i}(k)$ refers to the maximum value of the $i$ series and $y_{i}(k)$ refers to the original value of the $i$ series and $k$ row.

In the step 2, Grey relational coefficient was calculated via Eq. (2);

$$
\xi_{i}(k)=\frac{\Delta \min +\zeta \Delta \max }{\Delta 0_{i}(k)+\zeta \Delta \max } .
$$

Here, $\zeta$ is a distinguishing coefficient between 0 and 1 , $\Delta 0_{i}$ is the amount of deviation between the reference series and the normalization values, $\Delta$ min refers to the minimum value of the deviation sequence from the reference series and $\Delta$ max refers to the maximum value of deviation sequence from the reference series.

In the step 3, Grey relational degree was calculated by Eq. (3);

$$
\gamma_{i}=\frac{1}{n} \sum_{k=1}^{n} \xi_{i}(k) .
$$

\section{Results and discussion}

Influence of the cutting parameters on surface roughness ( $\mathrm{Ra}$ ) and cutting force $(\mathrm{N})$ on milling of a PMD 23 mold steel with $\mathrm{Al}_{2} \mathrm{O}_{3}+\mathrm{TiCN}$ coated inserts are discussed in this section.

\subsection{Optimization of experimental results for surface roughness and cutting force}

Taguchi $L_{9}$ experiment design, surface roughness and cutting force values used in the experimental step are shown in Table II. Grey relational analysis method was applied to the experimental results shown in Table IV, and the other steps (normalization, delta values, and Grey relational grade) results are given in Table V. The Grey relational coefficients were calculated using the Eq. (2).

The Grey relational degrees related to each experiment result were calculated (Fig. 1) and the experiments results were ranked in order from highest Grey relational degree. Results are presented in Tables V and VI.

As seen from the Tables $\mathrm{V}$ and VI, A1 (feed: $500 \mathrm{~mm} / \mathrm{min}$ ), B1 (spindle speed: $3500 \mathrm{rpm}$ ), and C2
TABLE V

Normalized data, delta values and Grey relational grade for conventional insert tool.

\begin{tabular}{c|c|c|c|c|c|c}
\hline \hline Exp. & \multicolumn{2}{|c|}{ Normalized Data } & \multicolumn{2}{c|}{ Delta Values } & \multicolumn{2}{c}{ Grey rel. grade } \\
\cline { 2 - 7 } no. & $\begin{array}{c}\text { Cutting } \\
\text { force }\end{array}$ & $\begin{array}{c}\text { Surface } \\
\text { roughness }\end{array}$ & $\begin{array}{c}\text { Cutting } \\
\text { force }\end{array}$ & $\begin{array}{c}\text { Surface } \\
\text { roughness }\end{array}$ & $\begin{array}{c}\text { GRA } \\
\text { values }\end{array}$ & $\begin{array}{c}\text { GRA } \\
\text { rank }\end{array}$ \\
\hline 1 & 1.000 & 0.636 & 0.000 & 0.364 & 0.789 & 3 \\
2 & 0.896 & 0.931 & 0.104 & 0.069 & 0.853 & 2 \\
3 & 0.849 & 1.000 & 0.151 & 0.000 & 0.884 & 1 \\
4 & 0.609 & 0.403 & 0.391 & 0.597 & 0.508 & 5 \\
5 & 0.324 & 0.476 & 0.676 & 0.524 & 0.457 & 6 \\
6 & 0.738 & 0.443 & 0.262 & 0.557 & 0.565 & 4 \\
7 & 0.000 & 0.000 & 1.000 & 1.000 & 0.333 & 9 \\
8 & 0.290 & 0.126 & 0.710 & 0.874 & 0.389 & 7 \\
9 & 0.171 & 0.251 & 0.829 & 0.749 & 0.388 & 8
\end{tabular}

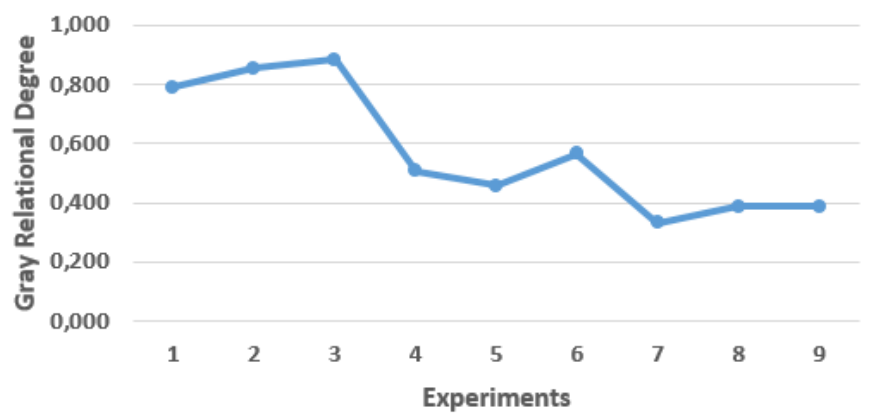

Fig. 1. Grey relational degrees for each experiment.

(cutting depth: $1.0 \mathrm{~mm}$ ) were selected as the optimal parameter levels. The optimal parameters levels correspond to the lowest surface roughness and cutting force value.

The Grey relational degrees related to each experimental result were calculated and the experimental results were ranked in order from highest Grey relational degree to be presented in Table VI.

TABLE VI

Grey relational degrees of the factor levels of milling.

\begin{tabular}{l|c|c|c}
\hline \hline Levels & $\begin{array}{c}\text { Feed } \\
\text { Fm/min] }\end{array}$ & $\begin{array}{c}(\mathrm{B}) \\
\text { Spindle } \\
\text { speed }[\mathrm{rpm}]\end{array}$ & $\begin{array}{c}(\mathrm{C}) \\
\text { Cutting } \\
\text { depth }[\mathrm{mm}]\end{array}$ \\
\hline Level I & 0.842 & 0.544 & 0.581 \\
Level II & 0.510 & 0.566 & 0.583 \\
Level III & 0.370 & 0.612 & 0.558
\end{tabular}

\section{Conclusions}

Useful results were obtained from this study in which machinability of PMD 23 cold-work tool steel with multilayer Al2O3+TiCN coated cutting tool was investigated. Criteria taken into account for machinability were surface roughness and cutting force. Three control factors (feed, 
spindle speed and cutting depth), which are considered to be effective for realization of these criteria at the ideal conditions, were chosen at three different levels and applied in the experimental study. Results are summarized as follows:

- The optimum value is obtained by Taguchi based Grey relational analysis when the machining parameters are as follows: $500 \mathrm{~mm} / \mathrm{min}$ feed, $3500 \mathrm{rpm}$ spindle speed and $1.0 \mathrm{~mm}$ cutting depth (A1B3C2).

- Taguchi method is beneficial for the experimental design of the machinability of PMD 23 cold-work tool steel alloy material. Having optimized the parameters, it is also fruitful for keeping the response values at required levels.

- The test results prove the effectiveness of the wiper inserts in providing excellent surface roughness. The results also suggest that the use of the wiper insert is an effective way to significantly increase cutting efficiency without changing the machined surface roughness in high feed turning operations.

\section{References}

[1] M.Y.L. Kris, A. Geddam, V.A. Ostafiev, Journal of Materials Processing Technology 89-90, 238 (1999).

[2] C.K. Toh, Journal of Materials Processing Technology 152, 346 (2004).

[3] L.O. Sotiris, A.C. Nearchoub, Robotics and Computer-Integrated Manufacturing 25, 73 (2009).

[4] V. Pateloup, E. Duc, P. Ray, International Journal of Machine Tools and Manufacture 44, 1343 (2004).

[5] B.K. Hinds, T.S. Ong, Journal of Materials Processing Technology 152, 339 (2004).

[6] A.K.M. Nurul Amin, S.B. Dolah, M.B. Mahmud, M.A. Lajis, Journal of Materials Processing Technology 201, 466 (2008).

[7] L.C. Brandao, R.T. Coelho, A.R. Rodrigues, Journal of Materials Processing Technology 199, 234 (2008).

[8] T. Chung-Chen, H. Hong, Journal of Materials Processing Technology 123, 1 (2002).

[9] J.A. Arsecularatne, L.C. Zhang, C. Montross, P. Mathew, Journal of Materials Processing Technology 171, 244 (2006).
[10] J.A. Ghani, I.A. Choudhury, H.H. Masjuki, Journal of Materials Processing Technology 153-154, 1062 (2004).

[11] K.A. Abou-El-Hossein, K. Kadirgama, M. Hamdi, K.Y. Benyounis, Journal of Materials Processing Technology 182, 241 (2007).

[12] H. Coldwell, R. Woods, P. Martin, P. Koshy, R. Dewes, D. Aspinwall, Journal of Materials Processing Technology 135, 301 (2003).

[13] K.A. Abou-El-Hossein, Z. Yahya, Journal of Materials Processing Technology 162-163, 596 (2005).

[14] J. Paro, H. Hanninen, V. Kauppinen, Journal of Materials Processing Technology 119, 14 (2001).

[15] N. Camuşcu, E. Aslan, Journal of Materials Processing Technology 170, 121 (2005).

[16] K.D. Bozuakis, N. Michalidis, S. Gerardis, M. Batsiolas, M. Papa, E. Lili, J. Miridis, J. Mueller, R. Cremer, Annals of the CIRP 56, 77 (2007).

[17] M. Okada, A. Hosokowa, R. Tanaka, T. Ueda, International Journal of Machine Tools and Manufacture 51, 127 (2011).

[18] H. Shao, L. Liu, H.L. Qu, Wear 263, 736 (2007).

[19] P. Koshy, R.C. Dewes, D.K. Aspinwall, Journal of Materials Processing Technology 127, 266 (2002).

[20] Y. Kita, H. Furuike, Y. Kakino, H. Nakagawa, T. Hirogaki, Journal of Materials Processing Technology 111, 240 (2001).

[21] J.G. Lima, R.F. Avila, A.M. Abrao, M. Faustino, J.P. Davim, Journal of Materials Processing Technology 169, 388 (2005).

[22] A. Richetti, A.R. Machado, M.B. Da Silva, E.O. Ezugwu, J. Bonney, International Journal of Machine Tools and Manufacture 44, 695 (2004).

[23] J.A. Ghani, I.A. Choudhury, H.H. Masjuki, Journal of Materials Processing Technology 153-154, 1062 (2004).

[24] T. Kivak, Measurement 50, 19 (2014).

[25] P.S. Sivasakthivel, R. Sudhakaran, S. Rajeswari, Proc. Inst. Mech. Eng., Part B: J. Engin. Manuf. 227, 1788 (2013).

[26] M. Ay, Acta Physica Polonica A 131(3), 349 (2017).

[27] G. Basmaci, M. Ay, Acta Physica Polonica A 131(3), 354 (2017).

[28] M. Ay, Y. Altunpak, S. Hartomacioğlu, Acta Physica Polonica A 131(3), 551 (2017). 